\title{
Inculturating Theology in the Indigenous Categories: The Quest for Filipino Cultural Identity
}

\author{
Michael M. Ramos
}

\begin{abstract}
Giving importance to indigenous categories is becoming more and more a must for Filipino theological articulators. It is through the utilization of indigenous categories that we could shape and develop the emerging Filipino consciousness and to express the gospel within the context of the people's own culture to effectively bring across it and identify it with the culture of the people; more so, for Christianity to become a folk Christianity, that is, Christianity expressed in the indigenous cultural way. However, there is a need to examine and analyze the methodology used by our Filipino theologians in articulating faith in the indigenous categories so as to determine the difficulty that confronts the process of inculturation.
\end{abstract}

Index Terms-Culture, cultural exegesis, inculturation, indigenous categories.

\section{INTRODUCTION}

The Philippines is known to be the only predominantly Christian country in Asia. As the Church has established itself in many parts of the land and continues to grow and is adopt authentic Filipino cultural beliefs and practices into its teaching, these phenomenon indicate that Christianity has totally taken root in Filipino culture and can be claimed that this Christianity becomes their own Christianity. Hence, the Philippine Church obtained an inculturated evangelization, that is, by which Christian faith is embodied and translated within a concrete historical and cultural situation through the process called inculturation. Vatican II Document [1] defines inculturation as: "The encounter of the Good News with cultures, an encounter which entails transformation of the authentic values of these cultures by their integration into Christianity..." For De Mesa [2], this simply means, "making Christianity not only be expressed but thought and lived in terms of the cultural tradition of the people to whom it is preached." Betzke [3], likewise, alluded that while the gospel integrates itself within a culture it does not seek to tear out the community's culture, nor does it intend to just add the gospel, rather it is an effort of the Church to make the gospel relevant to the people that, according to Aruppe [4], "in such a way that this experience not only finds expression through elements proper to the culture in question, but becomes a principle that animates, directs and unifies the culture, transforming and remaking it so as to bring about "a new creation." Therefore, Burke [5] explains that inculturation

Manuscript received April 4, 2014; revised June 25, 2014. This work is supported by the Office of Research and Publications, De La Salle Lipa.

Michael M. Ramos is with the Faculty of Religious Studies and Philosophy Area, De La Salle College - Lipa, Philippines (e-mail: mykramos1517@gmail.com). enriches the Church; for she uses in her preaching the discoveries of different cultures to spread and explain the message of Christ to all nations, to probe it and more deeply understand it, and to give it better expression in liturgical celebrations and in the life of the diversified community of the faithful.

Undoubtedly, we see how Christianity affected the Filipinos' religiosity and culture that now becomes part of our whole cultural system. This is very evident in various religious customs and traditions that manifests in the Filipino religiosity, that is, the Filipino spiritual relationship and their expressions in their liturgical life such as; rites and ceremonies, Fiestas, processions, pilgrimages, novenas, and innumerable devotional practices, both individual and communitarian, as well as on the level of faith reflection as a Church. Elesterio [6] explains that these religious beliefs and practices of Filipinos showed that even after centuries of evangelization, the common folk retained their pre-Christian beliefs and practices, valued the gospel and their culture and keeping both while professing their Christian faith. Hence it is just right to say that Filipino culture is inconceivable without its popular religious rituals. Practically, our religious practices relate a variety of religious spirituality that radiates the kind of spirituality that is ours as Filipinos.

Under such claim that the Philippine Church has obtained an inculturated evangelization it has become customary to lowland Filipino Catholic to use the abbreviated phrase “ ROMANO PO AKO" to designate his or her religious affiliation, which is obviously refer to Roman Catholicism. However, as Jose De Mesa [7] noted, naming oneself as "ROMANO" has a certain oddity about it and it reveals the nature of Catholicism in the Philippines, pointing to its western origins and expressions. From a historical view this situation is arguably understandable because Christianity had been brought to the Philippines from the West. Thus, this syllogism simply implies the logical premises that the Christianity we have inherited from our forefathers is not Filipino in origin but Western, therefore, Filipino Catholicism cannot be considered as our own Christianity.

From the foregoing, the question that arise here are the following: how much of the Filipino cultural system has influenced the faith they have received so that Christianity becomes the faith of the Filipino people? Has the Filipino culture really been inculturated? Has the gospel sufficiently taken root in our culture? Or perhaps, it is more like a question whether Filipinos had been truly Christianized or Christianity had simply been Filipinized. Hence, the problem of faith and culture abound for Filipino theologians and scholars lies in how to be authentically Filipino and authentically Christian in the culture that they find themselves in. 
This paper is an attempt to analyze inculturation in the Philippine theology, to establish a theoretical framework as a stage from which to assess the various attempts of inculturation. Likewise, there is an attempt to raise some questions on methods, based from the realization that these various ways of inculturation need to be involved and critically collaborated as each approach must have its readiness to listen to other points of view. It is also the task of this paper to argue that such a problem is rooted in one's theory of culture. It is from one's notion of culture that a theological methodology takes its frame. To be able to establish a conversation on theological method, there is a need to clarify a theologian's conception of culture.

In setting out on this research journey, for the purpose of theological examination and evaluation on how the appropriation of the Christian faith is done in the Philippine it will require us to look on the Philippine culture, considering the welter of regional and sub-regional cultural traditions existing at present, in order to examine how the gospel can be embedded in Filipino culture. Second, we will look on the various methods of inculturation acquired by our local theologians so as to engage the different theological approaches. Third, my modest aim is merely to bring out some arguments and comments in order to raise some issues on the theological methods employed by our prominent and respectful theologians.

\section{The PhilipPine CUlture}

There are various ways of understanding when we speak of a people's culture: their art; modes of behavior and social interaction; their customary laws and norms; their system of communication and language' their ways of thinking, symbols, worldviews, beliefs, and values. When we take a look on Philippine culture, one word that would best describe it would be diversity. As Fabella [8] illustrated, The Philippines is a diversity of peoples and cultures, experiences and traditions, this is because our land is an archipelago of over seven thousand islands, with its major island groups named Luzon, Visayas, and Mindanao. The geographical structure and location brings forth its multicultural faceted characteristic. There exist a variety of cultures and subcultures, with different ethnic origins, racial backgrounds, languages, customs and religious traditions that makes the definition of the "Filipino" not only diverse but also complex. Because of this, the Second Plenary Council of the Philippines [9] made the statement: "Ours is a pluralist society and a prime factor of our pluralism is the diversity of our cultural heritage. Lowland cultures have been heavily influenced by three centuries of Spanish colonial rule, the Muslim people of the south by Islamic traditions, and the mountain tribes, especially on Luzon, Mindanao and Mindoro, have retained much of their pre-spanish characteristics."

However, in all societies, it is suppose that the inner part of culture is the thinking, beliefs, worldviews, symbols, and behavior. This core part of culture, for the simplification of this concept, can be summed up under the rubric of values. Values are at the deepest level of culture; they are its heart and core. They are, for all intents and purposes, what give people their identity as a people, a distinct human society. From this concept of what values mean, as a unifying force of society, Graves [10] called it as value system. Graves She defines value system as a hierarchically-ordered, always open set of morals, ethics, standards, preferences, belief systems and worldviews that come together through self-organizing principles to define an individual, a group or a culture. Gripaldo accounted [11] what this perspective implies is that Filipino culture refers to the set of values or the value system that a majority of the Filipino have historically held important in their lives. This Philippine value system includes their own unique crowd of consistent ideologies, moral codes, ethical practices, etiquette, and cultural and personal values that are promoted by their society. As with any other society, the values that an individual holds sacred can differ on the basis of religion, upbringing and other factors. Hence, the distinct value system of Filipinos is rooted primarily in personal alliance systems, especially those based in kinship, obligation, friendship, religion and commercial relationships.

But despite of the difference or pluralistic view society in the country, we can still speak of a generic Philippine culture. By focusing on the structuring of our many of our social and ethnic groups and the basic values that go with that structuring, we see that the people, whether from the upland or lowland have a common structuring of social relations based on family and its well-being. Basic values, like family, loyalty, emphasis on authority and respect for elders, and among other things, are supportive of this sociological fact. The commonalities are more striking than the differences, and we can conclude that there is indeed a common culture and a common social structure that we can truthfully call Filipino.

Hallig [12] made a suggestion that by looking into the common culture and social structures, Filipino values are centered on keeping social harmony, objectively motivated to be within a group. Social approval, acceptance by a group, and belonging to a group are major concerns of Filipino values. The main sanction against diverging from these values are the concepts of "Hiya" or 'a sense of shame', and "Amor propio" or self-esteem. According to Leonardo Mercado, [13] the Filipino worldview is basically 'nondualistic'. Based on his linguistic analyses of Filipino value terms like "loob" he noted that Filipinos desire harmony, not only in interpersonal relationships, but also with nature and religion, while still remaining inseparable. This implies, "the Filipino wants to harmonize the object and the subject, while at the same time holding both as distinct." While others hold, Filipino values are based on the significance of the world to man. Life experiences dictate the philosophy of the Filipino, augmented by other sources like proverbs, folk sayings, folk tales, and the like.

The values we have termed traditional above are readily recognized by most of us as part of our culture. But they are not all we see. We are also observing some emergent values that have started to take root in Philippine society and now and again burst into public consciousness and play essential roles in our social life. Thus, it is possible for us to have not only long-held traditional values but also emergent ones, values that are in the process of being institutionalized in 
social structures and interactions.

The recognition of the importance of the context of the Philippine culture to which the message is being transmitted needs a hermeneutical understanding. This situation gives rise to the question what the Filipino perspective of the gospel is? It would be difficult to speak of a perspective from a Filipino culture and spirituality given that the country is so diversified. It seems that one no longer can speak of "Filipino culture " in general in a pure state because of its evident diversity and complexity. Hence, it is from this point that I have the impression that because of the dynamic and complex view on Philippine culture pervades much of the current theological discussion about inculturation so as to create a Filipino cultural identity. It is for this reason that I wish to explore the process of inculturation which is being employed by our Filipino theologians from the perspective of culture as a flowing phenomenon.

\section{The Process OF INCULTURATION}

According to De Mesa, [14] inculturation is the result of culturally defined and culturally embodied theological responses to the situation. Methodologically speaking, the theology begins with the issues, questions, and concerns of people within a particular situation. The actual human situation must be reflected in the light of the gospel in order to rediscover what the message of the gospel means to us. Hence, within the general principle of a mutually respectful and critical interaction between the Judaeo-Chrisitan tradition and the human situation, there is the possibility to give it a particular form and focus depending on the actual needs of the community. So just as the issues, questions and concerns of a local church are culturally and historically conditioned, so is the methodology utilized for actual doing of theology of inculturation. Because the questions and the method opted for are geared towards the actual situation, which calls for a Christian interpretation.

Moreover, doing theology as inculturation is not just a matter of looking at the way the culture is developing it is cooperation with the involvement in cultural development. (Positive resources of the culture to interpret both the situation and the faith tradition.) Accordingly, using culture as source for theology it leads us to a discovery, which is that of the relevance of the faith tradition in the actual situation. This will also allow us to discover the riches and strengths of the tradition and helps us to discern and challenge the limitations of the present cultural and historical embodiments of this tradition. Essentially inculturation is concerned with how the gospel and culture relate to one another across geographic space and down through time. This process captures in method and perspective the challenge of relating the gospel to culture. It is often used as a metaphor for the process by which the Church becomes present within a given cultural context.

Furthermore, Leonardo Mercado [15] explains that inculturation is not just simply putting on an external dress but rather it is internal, that is, taking away the foreign Christ and making him native in order that he will grow and bear fruit in the nation. Thus, this search for making Christ bear fruit in each culture is taken from the notion of incarnation because the incarnation of the logos serves as the model of transmitting the gospel to other cultures. With this model, the Church understands that in order to transmit the gospel within a specific cultural setting the gospel must be translated intelligible and relevant to particular cultures and situations. This process is known as Indigenization, which means "taking root in the soil"

In the Vatican II documents, [1] the term "adapt" was used to refer to indigenization. Rodrigo Tano [16] defines adaptation refers to the process by which components of a given culture are utilized to express the meaning of the gospel. Whereas Indigenization is a process of making the gospel message intelligible in the idiom of the language and culture of the receivers. Therefore, indigenization is a general term, which includes these concepts as they point to the process by which Christian message "takes root" and grows out of new cultural soils. In practice, however, indigenization meant the gradual replacement of foreign missionaries with cultural personnel and to give a cultural face to ecclesiastical structures, so that the Church may appear less foreign. Thus indigenization was intended to show that the Church was at home in a particular culture and that Christianity became truly the people's religion. In the Philippine indigenization is called Filipinization.

For Dionision Miranda, [17] who made a systematic search for native equivalents of moral terms current in ethical discussions, he argues that there is a need that Filipino moral thought to be Catholic must be familiar with the tradition. Hence, the task of Filipino moralist is to seek and grasp reality as it is and to express it through categories significant for his particular group. Such endeavor is not beyond possibility because the fact that morality is a universal phenomenon there implies a residue in experience that is common to all. At the same time, since morality is rooted in a socio-cultural medium, the same reality can be interpreted from different viewpoints, articulated differently, and communicated at various levels of complexity.

TABLE I: TYPES OF INCULTURATION THEOLOGIAN PROCESS DiSTINCTIVE METHODOLOGICAL CHARACTERISTIC ANALYSIS

\begin{tabular}{llll}
\hline $\begin{array}{l}\text { Jose } \\
\text { De Mesa }\end{array}$ & $\begin{array}{l}\text { Contextua- } \\
\text { Lization }\end{array}$ & $\begin{array}{l}\text { Past -Present } \\
\text { Culture/Context }\end{array}$ & $\begin{array}{l}\text { Cultural } \\
\text { Exegesis }\end{array}$ \\
\hline $\begin{array}{l}\text { Leonardo } \\
\text { Mercado }\end{array}$ & Indigeniza- & Residue of the & Cultural \\
Past (Culture) & Exegesis \\
\hline Dionisio & Vernacular & Indigenous & Cultural \\
Miranda & & Language & Exegesis \\
& & & (Dyanmic \\
& & & Equivalence) \\
\hline
\end{tabular}

Accordingly, the objectivity of cultural rethinking in ethics is to arrive at those native terms that coincide or at least meet with the conceptual meanings designated by the foreign terms, and to elevate them to some kind of technical status for such terms to appear as the language of the people. The need to communicate the gospel values culturally, contextually, and in vernacular to Filipino opens to the path to Filipino theological ethics. This is because theology should always articulate the gospel values in a way understandable to the people. It is likewise important to note that language of the people is a very important key factor for inculturation. 
Language identifies a people more than other traits, including customs, traditions, dressing, attitudes and other behavioral patterns. Hence, the effort to communicate the gospel values in the context of the Filipino and in its native language is to bring out an authentic inculturation, It ensures not only the relevance of the gospel but also the clarity and significance in meaning of the message.

As discussed in Table I, the above mentioned theologians in their process of inculturation share in one common ground as for the framework in doing theology. The mainstream theology can be said to start with the analysis of culture. De Mesa [18] is known as the pioneer of this approach, which he calls "theological re-rooting." The notion is taken from Kosuke Koyama's [19] Waterbuffalo's theology, which defines theological re-rooting as a "thoughtful attempt to translate the inner meaning of the message of Jesus Christ from one historical cultural milieu and root it into another." Accordingly, there is an intrinsic relationship between evangelization and theological re-rooting and this can be understood through the language of the culture itself. In the context of Christianity in the Philippines, our land has come through two successive colonization, by the Spaniards and Americans, because of these factors, Filipino minds have been trained to think the Christian Faith in its Western garbs. Thus, the objective to re-root the gospel is to deconstruct these colonial traces with which the faith was first presented. It seeks to strip Christianity of its "relatively bound formulation" so that the inner meaning of the message and its living core can be expressed in distinctly Filipino categories. De Mesa Alluded " the task today is that of bringing the same message to other people in terms of their own language and culture beginning with their own cultural values."

De Mesa [20] calls his theological method as cultural exegesis. He argues that since man is totally immersed in culture, culture itself becomes a second nature to him. This feel for culture is in effect the fundamental way in which theology can be done. He defines cultural exegesis as a hermeneutical act, which "intends to make explicit the meaning a culture holds." By cultural exegesis, some part of the past can be recovered which has some bearing on present questions, issues and needs. Otherwise such hermeneutic activity becomes irrelevant and out of touch with what is currently going on in the lives of people if the culture of the people will not be given any consideration. Thus, using the vernacular can be an important tool for delivering the gospel intelligible to the people for language is the most fundamental path to one's culture.

The works of our Filipino theologians in the process of inculturating theology in the indigenous categories clarify to the Filipino mind not only the dogmas which is being expressed in Western thoughts but also recovers the rich meaning of the culture itself that was lost due to colonial brainwashing. The insistence on using the vernacular and re-rooting the gospel in our culture gives us the sense to communicate, express, think, and discuss our faith in our own native language so as to live the faith we professed and to live by it in our own cultural way. However, I would like to forward two comments on this methodology: First, the notion of culture; and second on the method of cultural exegesis.

\section{Discussion}

Our prominent and respectful theologians, De Mesa, Mercado and Miranda, grounded their methodology on cultrural exegesis. Their notion of culture seemingly show that it refers to those socially transmitted patterns for behavior characteristic of a particular social group or civilization, that is, a complex whole which includes knowledge, belief, art, law, morals, custom, and any other capabilities and habits acquired by man as a member of society. Such notion of culture is vividly derive from the modern anthropological concept. This modern view emphasizes culture's role in generating social consensus, as people come to a shared experience of values. However, this modern perspective on culture has been contested and rejected by postmodernist. Against the view that cultures are clearly circumscribed, consisting of internally unified beliefs and values that are transmitted as principles of social order, the postmodern view stresses historicity, indeterminacy, fragmentation, and conflict. It rejects the modern tendency of previous students of culture to turn a blind eye to the social conflict and divergence of opinions that mark the struggles of a people to make sense of reality, as they either preserve, alter, or revolt against the terms of their world. Tending to intellectualize culture, the modern view ignores the conflicts, the turns and twists of real life situations, and downplays the power dimension in the interpretation of beliefs and values. From a postmodern perspective, cultures may have common elements, but rather than being articulated in apodictic terms, they remain vague and unelaborated. This lack of clear and categorical definitions, however, makes dialogue and interactions possible among people who are differently situated. Rather than a consensus-driven notion of culture is on whose meanings are plural and shift according to multivalent circumstances. Hence, I would like to propose to look at culture not simply as a structure rather on how postmodernist views what culture is.

In recent discourses on anthropology, culture is always described in a subjective notion, that is, worldviews, values, meanings, symbol, etc. This notion of culture is a passive connotation of pre-determined values, where people come to a shared experience of values. Piere Bordieu [21] noted that when cultural forms function as rules directing action, they do not resemble the rules of game or mathematical formulae that are mechanically applied and executed. Rather, cultural rules are applied with flexibility, creativity, and innovation, according to the complexity of social circumstances. The various ways of responding appropriately to cultural rules depend on the dictates and demands of human situations. People meet in a variety of centers where interactions are multileveled and exchanges are marked by imbalances and inequalities. The interconnections between and among cultures are not static and homogenous, but shifting and pluralistic. This suggests that culture is not linear and unchanging but a dynamic creation of dialogue, conflict, and negotiation within multileveled social progresses and interactions. Constituted by beliefs and values, customs, stories, and traditions that form a particular way of being human, culture emerges from historical processes and continues to evolve as its participants make sense of their experience in changing times and circumstances. By this 
notion, it is understood that culture is a process.

In line with the idea that culture is a process, Raymond Williams [22] defines culture as ordinary. Accordingly, every society has its own shape, its own purpose, and its own meanings, as he points out, "the making of society is the finding of common meanings and directions, and its growth is an active debate and amendment under the pressures of experience, contact, and discovery, writing themselves into the land." As the society grows, it is there that culture is made and remade in every individual mind. The making of a mind is the gradual learning of shapes, purposes, and meanings, so that work, observation and communication is possible. It is in this context that he speak of culture is ordinary, which are lived in real lives and in actual knowable communities, in "rooted settlements, lived, worked and placeable social identities." Thus, culture is a dialectical conjunction, with its accompanying tensions, between two differing worlds: between the traditional and the creative.

It is from this context that Williams [23] speaks of the creation of a common culture. Common culture does not refer to a uniform and single global culture rather it is both a critical concept and a socialist ideal. It is one whose meanings and values are created, not by a special or privilege minority, but from a complex process of articulation, it is a process wherein "the people as a whole participate in the articulation of meanings and values, and in the consequent decisions between this meaning and that, this value and that." Therefore, culture is a process, a material production and a common creation of a people.

The second comment is very much akin to the first. Our three theologians proposed to use the method of cultural exegesis so as to re-root the gospel in our culture. By this method, it enables to recover those cultural meanings and values which have potential for expressing the gospel so that they can be made to sacramentalize God's active presence in the world. Such an interpretative procedure can only be done from the insider's perspective. In other words, their position came from the notion of culture as a determinate structure of positive values within Filipino psyche or as a cultural context composed by past generations by which some determinate reality can be either recovered or interpreted. This understanding of culture as a structure and its relation to the gospel can be traced in part of the document of the Vatican II Council, specifically Gaudium et Spes. [24] The Council emphasized the priority of the gospel over culture, and some recent theorists seem to regard culture as the ultimate source and norm of faith. They argue that some elements of the gospel are already hidden in every culture, and the task of theologian is to bring this hidden gospel in light. Thus, there is a residual in culture which "has been effectively formed in the past, but still active in the cultural process, not only and often not all as an element of the past but as an effective element of the present." This would lead to the questions; Is there a cultural kernel to recover? Is it retrievable? From what I have proposed to see culture as a process, the method of cultural exegesis would not fit in the framework. The problem with the method of cultural exegesis comes form the notion of culture. Hence, Daniel Franklin Pilario [25] argued that "Cultural exegesis does not pre-determine or pre-judge that nature of a cultural practice from the outset. There is no way one can tell that a cultural practice is a positive resource and the other a negative trait before plunging into the uncertain forces of the cultural game itself. Its evaluation is only possible in the ambivalent and rough grounds of lived experience." This simply implies that culture emerges from historical processes and continues to evolve as its participants make sense of their experience in changing times and circumstances. By this notion, it is understood that culture is a process. That is why Bevans [26] claims that "there is no such thing as "theology"; there is only contextual theology...the attempt to understand Christian faith in terms of a particular context is really a theological imperative." $\mathrm{He}$ explains that all theology is contextual because theology is being conditioned by its context. In this sense, theology is done in a contextual manner that affects the context and aims at transforming it.

In this agonistic process, both in cultural praxis and theological endeavor, the theologians cannot pre-determine the gospel in a culture but only long and wait for God and experience to form a new Christianity that is to be lived by in their own cultural way.

\section{CONCLUSION}

The process of inculturation shows that every subsequent encounter between Christ's message and another culture takes a slightly different path. What is happening in practice is that two cultures meet and influence each other through a very complex process of cross-cultural communication, one of which has integrated the Christian message more or less deeply, while the other relies on its own religious tradition. Many methods and strategies has been put forward to explain this complex process of inculturation but at this juncture the idea of inculturation is more often a state of mind than a precisely defined methodology. The question is no longer how to inculturate theology but rather which forms of inculturation is more successful and apt.

It is important to look at the process of inculturation in the context of culture, seen through the eyes of social changes, especially the post-modern understanding of culture. One of the things forgotten here is the essentially dynamic character of any culture. Culture is not static: it adapts and changes according to the changing situation and it cannot go back to its original status. It implies the fact that cultural identity remains an important factor for the theologians but it is not the only factor of inculturation. Cultural identity and dynamism of culture must be taken into account in the inculturation process

I believe that our Filipino theologians had made their journey with gradually increasing self-awareness and sincerity to transmit the gospel to Filipino context. However, farther examination and investigation is needed to evaluate the status of inculturation in our theology today to see whether Filipino cultures had been truly Christianized or Christianity had simply been Filipinized, because inculturation is not simply "christianizing" cultural beliefs and practices of the indigenous rather, Aruppe [27] said; "the incarnation of the gospel in a particular culture, in such a way that this experience not only finds expression through elements proper to the culture in question, but becomes a principle that animates, directs and unifies the culture 
transforming and remaking it so to bring about a new creation."

\section{ACKNOWLEDGMENT}

I wish to express my special thanks to the Office of Research and Publication of De La Salle Lipa for the funding and support that enabled me to complete this research.

\section{REFERENCES}

[1] F. Austin, Vatican II: Ad Gentes Divinitus, Daugthers of St. Paul, Harrison, Philippines, 1984, p. 813.

[2] J. D. Mesa, in Solidarity with the Culture: Studies in theological Re-Rooting, Maryhill Press, Manila, 1987, p. 14.

[3] J. Bretzke. (1991). Minjung Theology and Inculturation in the Context of the History of Christianity in Korea. East Asian Pastoral Review 28 [Online].

Available: http://www.usfca.edu/fac-staff/bretzkesj/MinjungContext.pdf

[4] P. Aruppe, "Letter to the whole society on inculturation," in Studies in the International Apostolate of Jesuits, p. 7, 1978.

[5] C. Burke. (2005). Incultuiration: John Paul II and the Third World. Eas Asian Pastoral Review 1995. [Online]. Availble: http://eapi.admu.edu.ph/content/inculturation-john-paul-ii-and-third-w orld

[6] F. Elesterio, Pre-Magellanic Religious Elements in Contemporary Filipino Culture, De La Salle University Press. Manila, Philippines. 1989, pp. 56-59.

[7] J. D. Mesa, Why Theology is Never Far from Home, DLSU Publishing House, 2012, pp.1-3

[8] F. Virginia. (2008). Inculturating the Gospel: The Philipine Experience. [Online]. Available: http://www.theway.org.uk/Back/39Fabella.pdf

[9] The Second Plenary Council of the Philippines. (1999). Acts and Decrees, Pastoral Exhortation on Philippine Culture. [Online]. 18(19) Availble:

http://www.cbcponline.net/documents/1990s/1999-philippine_culture. html

[10] C. Graves. (2007). Value system. [Online]. Available: http://en.wikipedia.org/wiki/Value_system

[11] R. Gripaldo, Filipino Cultural Traits: Claro R. Ceniza Lectures, CRVP, 2005.

[12] J. Hallig. (2010). Communicating Holiness to the Filipinos. [Online]. Available:

http://didache.nts.edu/index.php?option=com_docman\&task=doc_vie w\&gid $=277 \&$ Itemid
[13] L. Mercado, Elements of Filipino Philosophy, Divine Word University Publication, 1976, pp. 45-47.

[14] J. D. Mesa, in Solidarity with the Culture: Studies in theological Re-Rooting, Maryhill Press, Manila, 1987, pp. 34-36

[15] L. Mercado, Doing Filipino Theology, Divine World Publication, 1997, p. 67.

[16] R. Tano, Theology in the Philippine Setting, New Day Publishers, 1981, p. 43.

[17] D. Miranda, Pagkamakatao: Reflection on the Theological Virtues in the Philippine Context, Divine Word Publications, Manila, 1987, pp. 78-80.

[18] J. D. Mesa, And God said, "Bahala na": The Theme of Providence in the Lowland Filipino Context, Quezon City: Mary Hill School of Theology, 1979.

[19] K. Koyama, Waterbuffalo Theology, Maryknoll, N.Y.: Orbis books, 1974, p. 121

[20] J. D. Mesa, "A hermeneutics of appreciation: approach and methodology," MST Review, no. 2, pp. 21-23, 2006.

[21] P. Bordieu, Outline of a Theory of Practice, Campbridge University, 1977, pp. 1-9.

[22] R. Williams, "Culture is Ordinary," in Resources of Hope: Culture, Democracy, Socialism, ed., Robin Gable. London: Verso, 1989, pp. $3-18$.

[23] R. Williams, Culture and Society, Coleridge to Orwell London: Hogarth Press, 1993, p. 300.

[24] A. Flannery, Vatican II: Gaudium et Spes, Daugthers of St. Paul, Harrison, Philippines, 1984, p. 903.

[25] D. Pilario, "The craft of contextual theology: towards a conversation on theological method in the Philippine context," Intercultural Forum of Theology and Philosophy, vol. 1, 2003, p. 29.

[26] S. Bevans, Models of Contextual Theology: Faith and Cultures Series, Orbis Books Publishing, 2002, p. 21.

[27] P. Aruppe, "Letter to the whole society on inculturation," in Studies in the International Apostolate of Jesuits, p. 7, 1978.

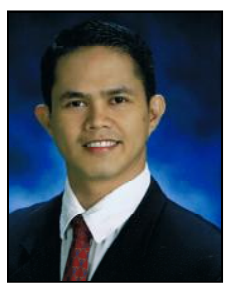

Michael M. Ramos was born in Muntilupa, Metro Manila on June 15, 1978. He is a fulltime faculty member of De La Salle Lipa-University in the Philippines. He is a graduate of AB Philosophy at St. Francis Regional Seminary, who took his M.A. in theology at Maryhill School of Theology, Manila and at present he is writing his dissertation on Inculturation for his Doctoral studies in applied theology at the De La Salle University- Manila. 